\title{
Cytochrome-c mediated a bystander response dependent on inducible nitric oxide synthase in irradiated hepatoma cells
}

\author{
M He', S Ye', R Ren', C Dong', Y Xie', D Yuan' and C Shao*,I \\ 'Institute of Radiation Medicine, Fudan University, No.2094 Xie-Tu Road, Shanghai 200032, China
}

\begin{abstract}
BACKGROUND: Radiation-induced bystander effect (RIBE) has important implication in tumour radiotherapy, but the bystander signals are still not well known.

METHODS: The role of cytochrome-c (cyt-c) and free radicals in RIBE on human hepatoma cells HepG2 was investigated by detecting the formation of bystander micronuclei (MN) and the generation of endogenous cyt-c, inducible nitric oxide (NO) synthase (iNOS), $\mathrm{NO}$, and reactive oxygen species (ROS) molecules.

RESULTS: When HepG2 cells were cocultured with an equal number of irradiated HepG2 cells, the yield of MN in the nonirradiated bystander cells was increased in a manner depended on radiation dose and cell coculture time, but it was diminished when the cells were treated with cyclosporin A (CsA), an inhibitor of cyt-c release. Meanwhile the CsA treatment inhibited radiation-induced $\mathrm{NO}$ but not ROS. Both of the depressed bystander effect and NO generation in the CsA-treated cells were reversed when $5 \mu \mathrm{M}$ cyt-c was added in the cell coculture medium. But these exogenous cyt-c-mediated overproductions of $\mathrm{NO}$ and bystander MN were abolished when the cells were pretreated with s-methylisothiourea sulphate, an iNOS inhibitor.

CONCLUSION: Radiation-induced cyt-c has a profound role in regulating bystander response through an iNOS-triggered NO signal but not ROS in HepG2 cells.

British Journal of Cancer (2012) 106, 889-895. doi:10.1038/bjc.2012.9 www.bjcancer.com
\end{abstract}

Published online 24 January 2012

(c) 2012 Cancer Research UK

Keywords: ionising radiation; bystander effect; cytochrome-c; iNOS; ROS

Ionising radiation induces DNA damage not only in the directly exposed cells but also in their neighbouring nonirradiated cells, termed as radiation-induced bystander effect (RIBE) that was first reported by Nagasawa and Little (1992). Since then, the research advance in RIBE has significantly impacted on the radiobiological studies and cancer risk evaluation. It has been known that a series of bystander responses, including cell killing (Lewis et al, 2001; Schettino et al, 2003), chromosomal damage (Lehnert and Goodwin, 1997), genomic instability (Seymour and Mothersill, 1997; Morgan and Sowa, 2007), neoplastic transformation (Sawant et al, 2001; Mancuso et al, 2008), changes in gene expression (Azzam et al, 1998), and DNA methylation (Ilnytskyy et al, 2009), can be triggered by the soluble molecules that are released from irradiated cells and affect neighbouring cells via gap junction (Azzam et al, 2000; Shao et al, 2003b) and/or culture medium (Baskar et al, 2007; Dickey et al, 2009). Because RIBE has an important implication in radiotherapy, tumour cells have been widely applied for the studies on this phenomenon (Shao et al, 2003a; Harada et al, 2009). Multiple RIBEs, including cell growth stimulation, DNA damage, and cell death, have been observed in tumour cells in vitro (Shao et al, 2003a, c; Gow et al, 2010). Using mouse model, the bystander responses of internal tumour cells or tissues were also confirmed

*Correspondence: Professor C Shao; E-mail: clshao@shmu.edu.cn Received 10 November 201 I; revised 21 December 201 I; accepted 5 January 2012; published online 24 January 2012 in vivo, and cancer-associated events, such as $p 53$ alteration, MMPs activity, and epigenetic change, were proved to be involved in the RIBE (Camphausen et al, 2003; Koturbash et al, 2007; Lemay et al, 2011).

Several bystander signalling molecules, such as free radicals (Narayanan et al, 1997; Shao et al, 2002; Han et al, 2009), proteins (Narayanan et al, 1999; Shao et al, 2008b), calcium flux (Lyng et al, 2002; Shao et al, 2006), and hormones (Shao et al, 2008a) have been disclosed. Recent studies have shown that cytochrome-c $(c y t-c)$ is also involved in the RIBE either as a sensor of bystander response (Yang et al, 2009) or as a signalling factor transmittable through gap junction (Peixoto et al, 2009). Our previous study demonstrated that a p53-dependent cyt-c release from the mitochondria of irradiated cells had an important role in the regulation of RIBE (He et al, 2011). cyt-c is an electron transporting protein and belongs to a part of the respiratory chain localised in the inner mitochondrial membrane (Schagger, 2002). Release of cyt-c from mitochondria into cytoplasm is a key event of radiation-induced apoptosis (Ogawa et al, 2002). However, most of the previous works have paid close attention in the role of cyt-c itself in RIBE but not its relationship with other bystander signals. To clarify the signalling pathways underlying the cyt-c-mediated bystander response, we detected two principal reactive species, that is, reactive oxygen species (ROS) and nitric oxide (NO), and attempted to determine which could be a downstream signal factor modulated by cyt-c in RIBE. 


\section{MATERIALS AND METHODS}

\section{Tumour Cell Line}

Human hepatoma HepG2 cells (Shanghai Cell Bank, Chinese Academy of Science, Shanghai, China) were cultured in Dulbecco's modified Eagle's medium (Hyclone Co., Beijing, China) supplemented with $10 \%$ fetal bovine serum (PAA Laboratories $\mathrm{GmbH}$, Cölbe, Germany), $100 \mathrm{U} \mathrm{ml}^{-1}$ penicillin, $100 \mathrm{U} \mathrm{ml}^{-1}$ streptomycin, and $2 \mathrm{~mm}$ glutamate. All cell cultures were maintained in a humidified atmosphere of $5 \% \mathrm{CO}_{2}$ in air at $37^{\circ} \mathrm{C}$.

\section{Cell irradiation, coculture, and drug treatment}

HepG2 cells were seeded onto a $26 \times 21 \mathrm{~mm}^{2}$ coverslip $\left(1.5 \times 10^{5}\right.$ cells) within a $35-\mathrm{mm}$ dish and allowed to grow overnight for cell attachment. Cells were then irradiated with $\gamma$-rays generated by a ${ }^{137} \mathrm{Cs}$ irradiator (Gammacell-40, Nordion International Inc., Kanata, ON, Canada) at a dose rate of $0.83 \mathrm{~Gy} \mathrm{~min}^{-1}$. Immediately after irradiation, the irradiated cells and nonirradiated cells growing on different coverslips were placed face-to-face with a 3-mm gap and cocultured in a $35-\mathrm{mm}$ dish with fresh medium until further assay.

In some experiments, HepG2 cells were pretreated with $5 \mu \mathrm{M}$ cyclosporin A (CsA, Sigma Co., St Louis, MO, USA) for $1 \mathrm{~h}$ and/or $500 \mu \mathrm{M} s$-methylisothiourea sulphate (SMT, Sigma Co.) for $10 \mathrm{~h}$ before irradiation. CsA is an inhibitor of mitochondrial permeability transition pore (MPTP) and SMT is a highly selective inhibitor of inducible NO synthase (iNOS) (Szabo et al, 1994). After irradiation, both drugs were immediately washed with PBS triply. Because CsA was stored $(1000 \times)$ in DMSO, 0.1\% DMSO was used as the control of CsA treatment. Some of the other cells were treated with $5 \mu \mathrm{m}$ exogenous cyt-c (Sigma Co.) by adding this reagent into the culture medium immediately after irradiation and persisted until the following measurements of micronuclei (MN), ROS, or NO.

\section{MN assay}

Formation of MN were measured with the cytokinesis block technique that has been widely used to estimate genotoxic damage (Fenech, 2007). Briefly, after irradiation and cell coculture, HepG2 cells were treated with $2 \mu \mathrm{g} \mathrm{ml}^{-1}$ cytochalasin-B (Sigma Co.) for $28 \mathrm{~h}$ followed by $0.075 \mathrm{M} \mathrm{KCl}$ hypotonic treatment for $3 \mathrm{~min}$ and then fixed in situ with methanol-acetic acid $(9: 1 \mathrm{v} / \mathrm{v})$ for $20 \mathrm{~min}$. Air-dried cells were stained with $20 \mu \mathrm{g} \mathrm{ml}^{-1}$ acridine orange (Sigma Co.) for $3 \mathrm{~min}$. $\mathrm{MN}$ were scored in at least 1000 binucleated cells each sample under a fluorescence microscope (Olympus, Tokyo, Japan). The MN yield, $Y_{\mathrm{MN}}$, was calculated as the ratio of the number of $\mathrm{MN}$ to the number of scored binucleated cells.

\section{Immunofluorescence localisation of cyt-c}

Intracellular cyt- $c$ was immunocytochemically detected in situ. Briefly, HepG2 cells $\left(5 \times 10^{4}\right.$ cells) were grown on a glass coverslip for $24 \mathrm{~h}$ before irradiation. $12 \mathrm{~h}$ after irradiation, HepG2 cells were washed with PBS and fixed with $4 \%$ paraformaldehyde for 20 min then incubated with $3 \%$ BSA plus $0.5 \%$ Triton X-100 in PBS for $1 \mathrm{~h}$ to permeabilise the cells and block nonspecific protein interaction. Subsequently, these cells were incubated overnight with the sheep polyclonal cyt- $c$ antibody (Abcam, Cambridge, MA, USA) at a $1: 100$ dilution at $4{ }^{\circ} \mathrm{C}$. After removing the unbound antibody by rinsing with PBS, the cells were incubated with FITC-labeled rabbit anti-sheep IgG $(\mathrm{H}+\mathrm{L})$ conjugate (Invitrogen, Carlsbad, CA, USA) at a $1: 200$ dilution for $1 \mathrm{~h}$ in dark. Cell nuclei were stained with $100 \mathrm{ng} \mathrm{ml}^{-1}$ DAPI (Sigma Co.) for $2 \mathrm{~min}$. The stained cells were then secured with coverslip and sealed with mounting medium
(Vector Laboratories, Burlingame, CA, USA). The cell fluorescence image was captured with the MicroPublisher digital camera (QImaging, Surrey, BC, Canada) mounted on a fluorescence microscope (Olympus) and analysed with the Image-Pro Plus software (Media Cybernetics, Inc., Bethesda, MD, USA). Cyt-creleased cells (cyt- $c$ was diffusely expressed in cytosol) and cyt- $c$ concentrated cells (cyt- $c$ was concentrated relatively in mitochondria around the nucleus) were respectively counted in 10 randomly chosen fields. Approximately, 100 cells from each sample were analysed for the cyt- $c$ distribution assay.

\section{Western Blot Analysis}

After the treatments described above, the culture cells $\left(2 \times 10^{6}\right)$ were harvested and treated with the RIPA lysis (Beyotime Biotechnology, Shanghai, China) containing phosphatase inhibitor cocktail $(1: 100)$ (Sigma Co.) and phenylmethanesulfonyl fluoride (1 mM) (Sigma Co.) for $5 \mathrm{~min}$ on ice. Cell lysate was centrifuged at $12000 \mathrm{rpm}$ at $4{ }^{\circ} \mathrm{C}$ for $5 \mathrm{~min}$. Supernatant was collected and total protein concentration was quantified by the bichinconinic acid protein assay kit (Beyotime Biotechnology). Cell lysate $(40 \mu \mathrm{g}$ protein) was boiled in sodium dodecylsulphate (SDS) buffer for $10 \mathrm{~min}$ before electrophoresis on $10 \%$ SDS-polyacrylamide gel. After transfer to polyvinylidene fluoride membrane (Millipore, Bedford, MA, USA), the blots were blocked with $5 \%$ fat-free dry milk-PBST (PBS containing $0.1 \%$ Tween-20) for $1 \mathrm{~h}$ at room temperature. The membrane was incubated for $16 \mathrm{~h}$ at $4{ }^{\circ} \mathrm{C}$ with 1:1000 dilution of primary antibodies for iNOS (Cell Signaling Technology, Danvers, MA, USA) and $\alpha$-Tubulin (Beyotime Biotechnology). Blots were washed three times with PBST at $5 \mathrm{~min}$ intervals followed by incubation with $1: 2500$ dilution of respective horseradish peroxidase-conjugated secondary antibody (Cell Signaling Technology) for $1 \mathrm{~h}$ at room temperature. The transferred proteins were visualised with the ChemiDoc XRS system (Bio-Rad Laboratories, Hercules, CA, USA) using an ECL detection kit (Millipore) and analysed with the Quantity One software (Bio-Rad Laboratories).

\section{Measurement of intracellular ROS and NO}

The intercellular ROS and NO were measured in situ by using fluorescence probes of $2^{\prime}, 7^{\prime}$-dichlorofluorescein diacetate (DCFH-DA) and 3-amino,4-aminomethyl -2',7'-difluorescein diacetate (DAF-FM-DA) (Molecular Probes, Eugene, OR, USA), respectively. Briefly, after irradiation, HepG2 cells seeded on 24-well plates $\left(1 \times 10^{5}\right.$ cells) were treated with $3 \mu \mathrm{M}$ DCFH-DA or $5 \mu \mathrm{M}$ DAF-FM$\mathrm{DA}$ for $30 \mathrm{~min}$ at $37^{\circ} \mathrm{C}$ in dark, then additional dye was washed with PBS and the cells were incubated for an additional $30 \mathrm{~min}$ at $37^{\circ} \mathrm{C}$ in order for a complete de-esterification of the intracellular diacetates. The fluorescence intensity was then recorded by a microplate reader (Synergy HT, BioTek, Winooski, VT, USA) with an excitation wavelength of $488 \mathrm{~nm}$ and an emission wavelength of $525 \mathrm{~nm}$ for DCFH or an excitation wavelength of $495 \mathrm{~nm}$ and an emission wavelength of $515 \mathrm{~nm}$ for DAF-FM. The relative levels of ROS and NO were calculated as the mean fluorescence intensity of irradiated cells compared with the mean intensity of control cells without irradiation.

\section{Statistical analyses}

The data presented as mean \pm s.e. were obtained from two or three independent experiments with three replicates in each. Comparison is performed by the Student's two-tailed $t$-test, whereas multiple comparisons are carried out using one-way analysis of variance. Statistical significance is acceptable at the level of $P<0.05$. Data are analysed with the software SPSS11.5 (SPSS Inc., Chicago, IL, USA). 


\section{RESULTS}

\section{Radiation-induced direct and bystander damage}

Figure 1A illustrates that, as a consequence of DNA strand breaks, MN were induced in the irradiated HepG2 cells and its yield increased with dose. When nonirradiated HepG2 cells were cocultured with the irradiated cells for $12 \mathrm{~h}$, MN were induced in the bystander cells. The yield of bystander MN increased when the radiation dose increased to $3 \mathrm{~Gy}$, but then had a tendency of decrease at higher doses even nonsignificantly. The bystander response also had a relationship with the cell coculture time. When the target cells were irradiated with $3 \mathrm{~Gy}$ of $\gamma$-rays, the maximum bystander damage appeared at $12 \mathrm{~h}$ during the coculture period from 4 to $24 \mathrm{~h}$ (Figure 1B). Accordingly, $12 \mathrm{~h}$ post $3 \mathrm{~Gy}$ irradiation was an ideal condition for the induction of a bystander response in HepG2 cells and hence was chosen as the representative point for the following mechanistic investigations.

\section{Influence of cyclosporin-A and cyt-c on radiation responses}

To explore the potential role of mitochondria in radiation damage, $1 \mathrm{~h}$ before irradiation, HepG2 cells were treated with CsA to close the mitochondrial membrane pores and inhibit cyt- $c$ release. It was found that this treatment not only decreased the yield of radiationinduced $\mathrm{MN}$ by about $70 \%$ but also significantly diminished the MN formation in the bystander cells (Figure 2), which indicates that the mitochondrial function may be involved in the RIBE.

To obtain more evidence of cyt-c being involved in RIBE, exogenous cyt- $c$ was added into the medium during coculture of irradiated and bystander cells, and then the $\mathrm{MN}$ in both cells were
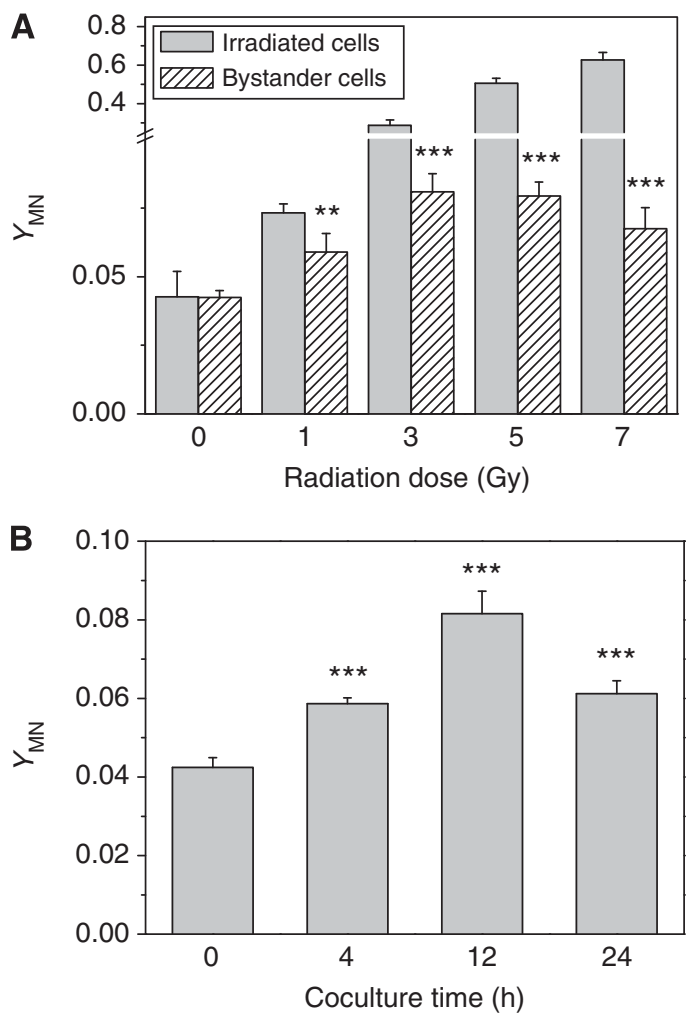

Figure I (A) Dose response of the yield of MN in the irradiated HepG2 cells and bystander HepG2 cells that were cocultured with irradiated cells for $12 \mathrm{~h}$. (B) Time response of bystander MN formation in HepG2 cells that were cocultured with $3 \mathrm{~Gy} \gamma$-irradiated HepG2 cells. $* * P<0.0$ I, **** $P<0.00$ I compared with the control without irradiation. measured. The results showed that although CsA bolcked the induction of bystander $\mathrm{MN}$, when the cells were treated with $5 \mu \mathrm{M}$ cyt- $c$ in substitution for intrinsic cyt- $c$ in the CsA-treated cells, the yield of $\mathrm{MN}$ in bystander cells was partly recovered from 0.056 of CsA-treated cells to 0.068 , but this exogenous cyt- $c$ failed to increase the MN yield in the directly irradiated cells under CsA treatment (Figure 2). In addition, this exogenous cyt- $c$ treatment itself had no influence on the MN induction of both irradiated and bystander cells. These data suggest that, as a critical event, cyt- $c$ could be involved in RIBE rather than direct radiation damage.

\section{CsA inhibited cyt-c release in the irradiated cells}

To know the situation of cyt-c release, we measured the distribution of cyt-c inside the cytoplasm of HepG2 cells with and without irradiation by the method of immuocytochemistry in situ. As shown in Figure 3A, for most of the nonirradiated HepG2 cells, the cellular cyt-c protein was concentrated inside mitochondria. After $3 \mathrm{~Gy}$ exposure, the cyt-c was released from mitochondria and diffused in the whole cytosol so that the percentage of cyt-c-released cells was increased from $35 \%$ of control to $60 \%$. However, this cyt-c release was effectively inhibited by $5 \mu \mathrm{M}$ CsA so that the percentage of the cyt-c-released cells significantly decreased to a level near control (Figure 3B), which is in parallel with the result in Figure 2 that CsA diminishes RIBE on $\mathrm{MN}$ induction.

\section{Generation of radiation-induced NO and ROS}

Two established bystander signalling molecules of NO and ROS were assayed after $3 \mathrm{~Gy}$ irradiation. Figure $4 \mathrm{~A}$ illustrates that the fluorescence intensity of DAF-FM corresponding to the intracellular NO was accumulated in the irradiated HepG2 cells over the time from 2 to $12 \mathrm{~h}$ postirradiation and it was significantly increased to about 1.5 -fold of the control at $12 \mathrm{~h}$ postirradiation. Normally, the intracellular NO is a reaction product of L-arginine catalysed by iNOS. Figure 4B shows that the level of iNOS expression was increased gradually after irradiation and it approached to 1.4-fold of the nonirradiated control at $6 \mathrm{~h}$ postirradiation and then became relatively stable up to $12 \mathrm{~h}$ after irradiation.

Figure $4 \mathrm{~A}$ also revealed the time response of radiation-induced ROS that was represented by the relative fluorescence intensity of DCFH in the irradiated cells. It was seen that the kinetics of the intracellular ROS was different from the generation of intracellular

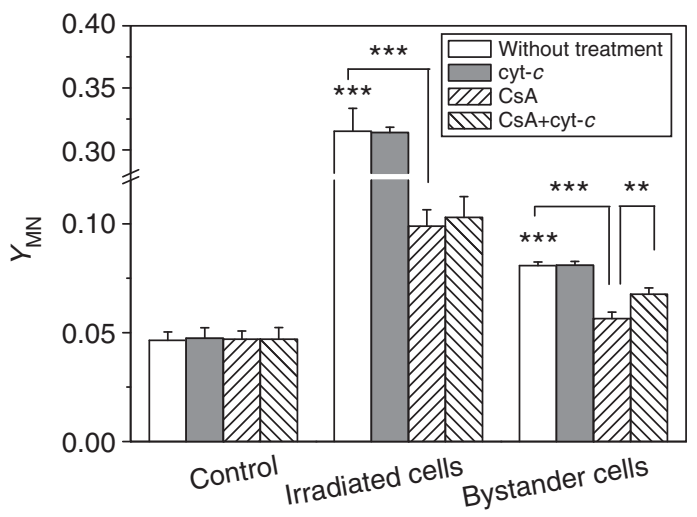

Figure 2 Influence of $\mathrm{Cs} A$ and exogenous cyt-c on the MN formation of 3 Gy $\gamma$-irradiated HepG2 cells and bystander HepG2 cells, which was cocultured with $3 \mathrm{~Gy} \gamma$-irradiated cells for $12 \mathrm{~h}$. $* * P<0.0$ I, **** $P<0.00$ I compared with the control without irradiation or to the indicated group with drug treatment. 
A

CsA treatment
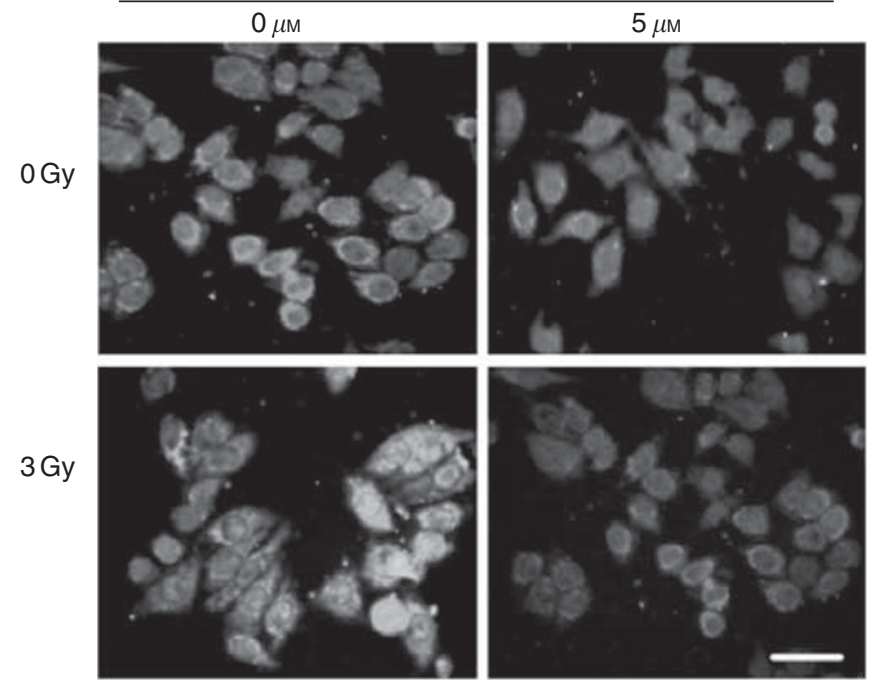

B

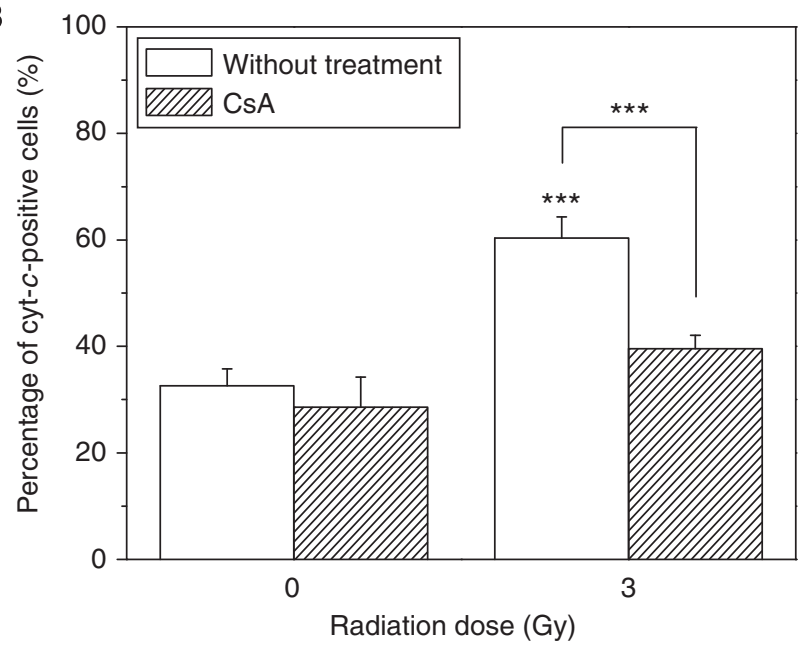

Figure 3 Typical fluorescence image of the distribution of cyt-c in HepG2 cells (A) and percentage of cyt-c-positive cells in the HepG2 population (B) $12 \mathrm{~h}$ after $3 \mathrm{~Gy} \gamma$ irradiation. In some experiments, HepG2 cells were pretreated with $5 \mu \mathrm{M}$ CsA for I h before the irradiation. Green fluorescence indicated cyt-c, blue fluorescence indicated nuclei. Scale bar, $20 \mu \mathrm{m}$. **** $P<0.00$ I compared with the control without irradiation or CsA treatment. The colour reproduction of this figure is available at the British Journal of Cancer online.

NO. ROS was induced immediately after irradiation and its yield increased rapidly to a maximum level at $2 \mathrm{~h}$ after irradiation and then decreased gradually to the control level at $4-12 \mathrm{~h}$ postirradiation.

\section{Relationship between radiation-induced cyt-c and NO, ROS}

To know the relationship between cyt- $c$ and radiation-induced free radicals, we treated cells with a MPTP inhibitor before irradiation. It was found that when the cells were treated with $5 \mu \mathrm{m}$ CsA before irradiation, the induction of intracellular NO decreased significantly but still higher than that of nonirradiated control. When the culture medium contained $5 \mu \mathrm{M}$ cyt-c together with CsA, the intracellular level of $\mathrm{NO}$ in the irradiated cells was recovered to the level of directly irradiated cells without any drug treatment (Figure $5 \mathrm{~A}$ ). These results disclose that the radiation-induced NO is regulated by the release of mitochondrial cyt-c.
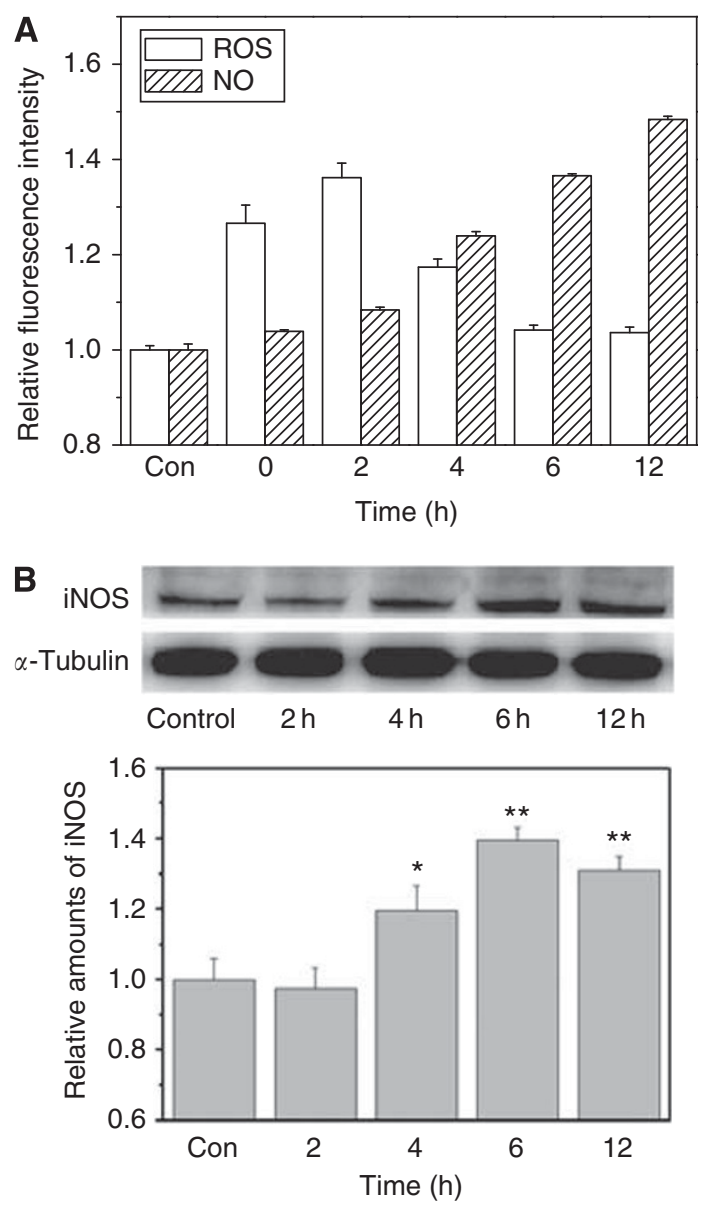

Figure 4 Time course of expression of ROS, NO, and iNOS postirradiation. (A) The column plots showed the relative intensity of DCFH and DAF-FM that were calculated as the mean intensity of experimental group cells compared with the mean intensity of control cells. (B) The relative expression level of iNOS examined by western analysis that was normalised to $\alpha$-tubulin first and then the ratio of each normalised value to the control value was calculated. ${ }^{*} P<0.05$, ${ }^{*} * P<0.0$ I compared with the control without irradiation.

More interestingly, although the fluorescence of DCFH in the irradiated cells was effectively reduced when the cells were treated with CsA alone, at the representative time points of 2 and $12 \mathrm{~h}$ postirradiation, it was uneventful in the CsA-treated HepG2 and had no relationship to the exogenous cyt-c treatment (Figure 5B). Thus, the generation of ROS was not a downstream event of cyt- $c$ release. Taken together, our results indicated that NO, rather than ROS, was a downstream product of radiation-induced cyt- $c$ release. This finding is coincident with our previous report that NO and ROS were involved in the bystander responses triggered by irradiated tumour cells and normal cells, respectively (Shao et al, 2005).

\section{Relationship between iNOS and cyt-c in NO-mediated RIBE}

Based on our above results, it can be foreseen that radiationinduced accumulation of iNOS might have a great effect on RIBE. This was confirmed by the result that the treatment of cells with SMT completely suppressed the bystander DNA damage (Figure 6A) and also greatly decreased the level of radiationinduced NO (Figure 6B).

Further experiment was performed to investigate whether iNOS and $c y t-c$ are independent of each other in the NO production and its downstream bystander response. Figure 6C illustrates clearly 

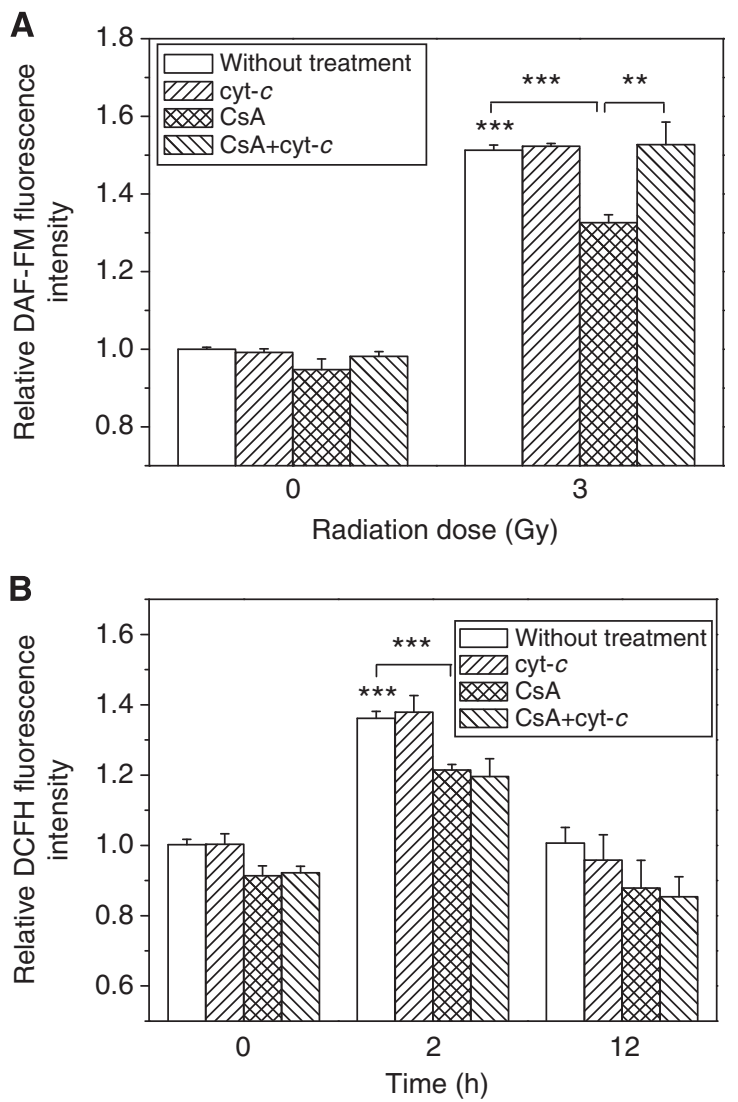

Figure 5 Influence of exogenous cyt-c on the induction of $\mathrm{NO}$ and ROS in HepG2 cells. (A) Relative intensity of NO-induced DAF-FM fluorescence in HepG2 cells $12 \mathrm{~h}$ postirradiation. (B) Relative intensity of ROS-induced DCFH fluorescence in HepG2 cells 2 and $12 \mathrm{~h}$ postirradiation. In some experiments, the irradiated HepG2 cells were pretreated with $5 \mu \mathrm{M}$ CsA before irradiation. $* * * * P<0.001$ compared with the control without irradiation and ${ }^{*} * P<0.01$, **** $P<0.00$ I between indicated groups.

that neither CsA nor exogenous cyt-c had any effect on the iNOS expression at $12 \mathrm{~h}$ postirradiation, indicating that iNOS was not a downstream molecule of the intracellular cyt-c. Considering from the opposite side, we pretreated HepG2 cell with an iNOS inhibitor SMT and then reexamined the cyt-c/NO-mediated RIBE. The results showed that although CsA could still somewhat attenuate the radiation-induced NO production, there were no any increases of NO (Figure 6B) and attendant bystander MN in the irradiated HepG2 cells in the presence of exogenous cyt- $c$ and iNOS inhibitor (Figure 6A). All of the above results indicated that, as an initial source of NO, the iNOS expression was essential to cyt-c/NOmediated bystander response.

\section{DISCUSSION}

The present study found that the bystander MN could be induced in the nonirradiated HepG2 cells after coculturing with irradiated cells and its yield was dependent on both radiation dose and coculture time, which was consistent with some of the other reports (Harada et al, 2008; Asur et al, 2009). It can be assumed that the level of bystander response might correspond to radiationinduced cellular damage, but once the cell damage was too serious to be insufficient in generating more bystander signals, the RIBE would reach to a platform and even then descent as that shown in Figure 1A.

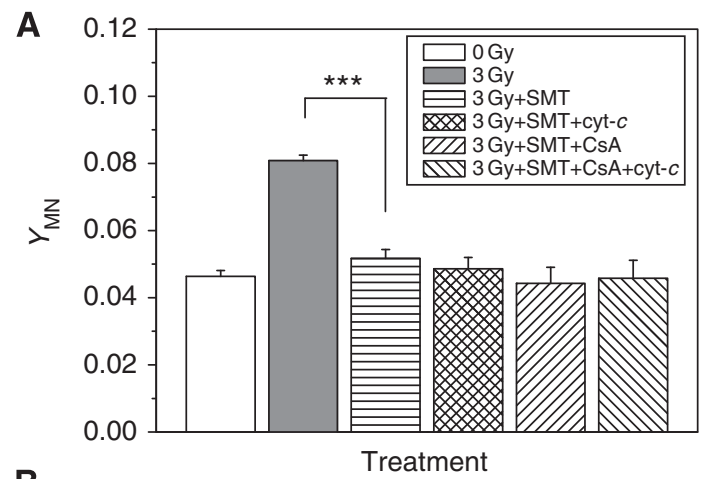

B
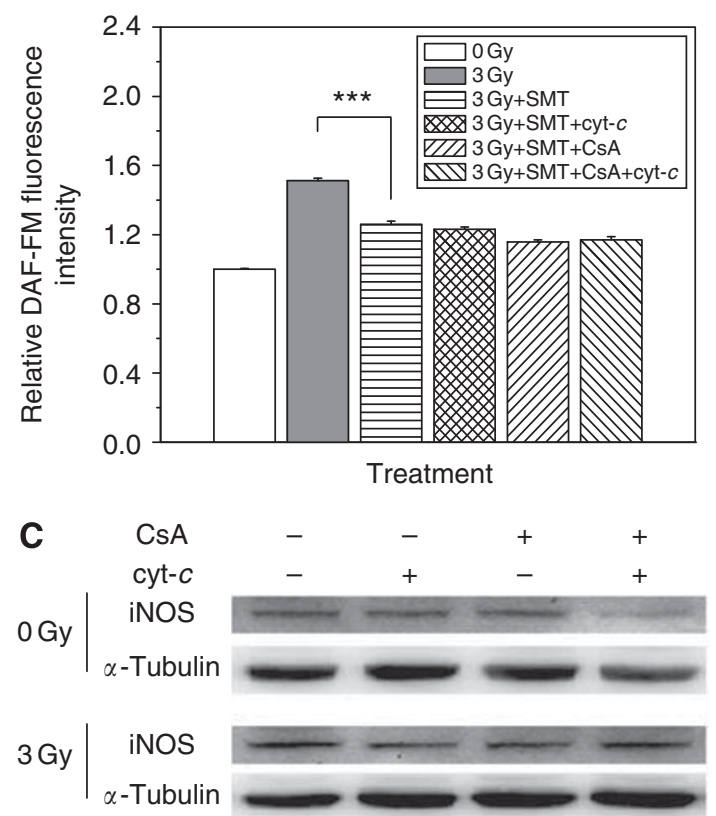

Figure 6 Cyt-c-mediated RIBE through $\mathrm{NO}$ in an iNOS-dependent pathway. Influence of iNOS inhibitor SMT on radiation-induced bystander $\mathrm{MN}(\mathbf{A})$ and $\mathrm{NO}$ production (B). In some experiments, the irradiated HepG 2 cells were treated with $5 \mu \mathrm{M}$ CsA for I h before irradiation and/or $5 \mu \mathrm{M}$ cyt-c for $\mathrm{I} 2 \mathrm{~h}$ after radiation. $* * * * P<0.00 \mathrm{I}$ compared with the control without irradiation. (C) Effect of CsA and cyt-c on the expression of iNOS induced by radiation.

RIBE is also related to the cell situation. It was found here that, even at an optimum condition of RIBE, the bystander MN could be nearly eliminated by the treatment of cells with CsA, indicating that mitochondria-dependent intracellular factor(s) may be involved in the stimulation of bystander response. The result of immunocytochemical assay provided a clue that cyt-c has a possibility to have a key role in the generation of bystander effect. These conjecture was confirmed by the data that supplement of exogenous cyt- $c$ into cell coculture medium partly recovered the bystander MN induction, which had been blocked by CsA, that is, the exogenous cyt-c could substitute the function of endogenous cyt- $c$ and then stimulates irradiated cells to generate some unknown bystander signalling factors and further induce cellular damage in adjacent cells. However, for the directly irradiated cells, the yield of MN in the CsA-treated HepG2 cells could not be recovered by exogenous cyt- $c$. Accordingly, the cyt- $c$ release may be essential for RIBE but is not a key point for direct radiation damage.

Mitochondria is the main pool of radiation-induced cyt- $c$ associated with the generation of free radical signals of $\mathrm{NO}$ and 
ROS (Chen et al, 2003; Aykin-Burns et al, 2011) that could act as important mediators of RIBE (Azzam et al, 2004; Shao et al, $2008 \mathrm{c}$ ). NO is postulated to be produced from L-arginine catalysed by iNOS (Nathan, 1992) after irradiation (Matsumoto et al, 2001), and it can act as an intercellular signalling molecule, cause DNA damage, and disturb DNA repair in bystander cells (Han et al, 2007). Our previous study showed that the amount of NO released from irradiated tumour cells was related to the dose and LET of irradiation, and suggested that radiation-induced NO might be modulated by some unknown factors during cell-programmed death (Shao et al, 2001). The present study observed that the generation of NO in the irradiated cells could be significantly inhibited by the treatment of cells with a MPTP inhibitor CsA, but this inhibition could be fully recovered when the exogenous cyt-c was supplied to the CsA-treated cells, which confirms that the NO generation is associated with mitochondrial cyt-c release in the process of apoptosis.

So far, there are a great deal of interests in the possibility that NO might be generated by a source other than NO synthase, such as the release of $S$-nitrosothiols during deoxygenation (Stamler et al, 1997) or the reduction of $\mathrm{NO}_{2}^{-}$to $\mathrm{NO}$ by haemoglobin (Cosby et al, 2003). The precise mechanisms of NOS-regulated intracellular NO and its redox state operated by mitochondrial $c y t-c$ were also widely discussed (Torres et al, 2000; Palacios-Callender et al, 2007). Therefore, it is quite essential and interesting to know the role of iNOS in cyt-c-mediated NO generation and bystander effect. We found here that the inhibition of iNOS could suppress the cyt-c-mediated RIBE by blocking the source of NO, thus the cyt-cl NO-mediated bystander effect was in an iNOS-dependent manner. Based on the present findings we hypothesise that cyt- $c$ has an important role in an efficient cascade amplification of the overproduction of NO generated from an iNOS-catalysed reaction.
It is well known that ROS also has an essential role in RIBE (Yang et al, 2005) and recent studies make further improvements that mitochondria-dependent ROS was very important in mediating bystander effects (Chen et al, 2009). As radiation-induced secondary factors, ROS contributed to the radiation-induced DNA double-strand breaks (Riley, 1994) and could concurrently trigger the release of cyt- $c$ from mitochondria in the irradiated cells (Chen et al, 2009; Ogura et al, 2009). That the ROS level in irradiated HepG2 cells was reduced by CsA but not recalled by exogenous cyt- $c$ may be the reason why the bystander $\mathrm{MN}$ in the CsA-treated cells was just partly recovered by the exogenous cyt-c that could recall the NO level in the CsA-treated cells. An interesting finding here was that the generations of intracellular level of ROS and NO in the irradiated cells had different kinetics. During $12 \mathrm{~h}$ postirradiation, ROS increased at first then returned back to a low level, whereas the NO production showed a cumulative effect. It can be proposed that radiation-induced generation of ROS is mainly responsible for direct DNA damage and the early event of bystander effect, meanwhile NO as a persistent bystander signal during cell coculture (Shao et al, 2004) is a source of integral process of bystander responses. Taken altogether, our data suggest that the event of radiation-induced cyt-c release can modulate NO generation, as a direct bystander signal via an iNOS-dependent mechanism in irradiated hepatoma cells, leading to MN formation in these bystander cells.

\section{ACKNOWLEDGEMENTS}

This study was supported by the National Nature Science Foundation of China (Grant Nos. 31070758, 11179002).

\section{REFERENCES}

Asur RS, Thomas RA, Tucker JD (2009) Chemical induction of the bystander effect in normal human lymphoblastoid cells. Mutat Res 676: $11-16$

Aykin-Burns N, Slane BG, Liu AT, Owens KM, O'Malley MS, Smith BJ, Domann FE, Spitz DR (2011) Sensitivity to low-dose/low-LET ionizing radiation in mammalian cells harboring mutations in succinate dehydrogenase subunit $C$ is governed by mitochondria-derived reactive oxygen species. Radiat Res 175: $150-158$

Azzam EI, de Toledo SM, Gooding T, Little JB (1998) Intercellular communication is involved in the bystander regulation of gene expression in human cells exposed to very low fluences of alpha particles. Radiat Res 150: $497-504$

Azzam EI, de Toledo SM, Little JB (2004) Stress signaling from irradiated to non-irradiated cells. Curr Cancer Drug Targets 4: 53-64

Azzam EI, de Toledo SM, Waker AJ, Little JB (2000) High and low fluences of alpha-particles induce a G1 checkpoint in human diploid fibroblasts. Cancer Res 60: 2623-2631

Baskar R, Balajee AS, Geard CR (2007) Effects of low and high LET radiations on bystander human lung fibroblast cell survival. Int J Radiat Biol 83: $551-559$

Camphausen K, Moses MA, Menard C, Sproull M, Beecken WD, Folkman J, O'Reilly MS (2003) Radiation abscopal antitumor effect is mediated through p53. Cancer Res 63: $1990-1993$

Chen Q, Chai YC, Mazumder S, Jiang C, Macklis RM, Chisolm GM, Almasan A (2003) The late increase in intracellular free radical oxygen species during apoptosis is associated with cytochrome c release, caspase activation, and mitochondrial dysfunction. Cell Death Differ 10: $323-334$

Chen S, Zhao Y, Zhao G, Han W, Bao L, Yu KN, Wu L (2009) Up-regulation of ROS by mitochondria-dependent bystander signaling contributes to genotoxicity of bystander effects. Mutat Res 666: 68-73

Cosby K, Partovi KS, Crawford JH, Patel RP, Reiter CD, Martyr S, Yang BK, Waclawiw MA, Zalos G, Xu X, Huang KT, Shields H, Kim-Shapiro DB, Schechter AN, Cannon 3rd RO, Gladwin MT (2003) Nitrite reduction to nitric oxide by deoxyhemoglobin vasodilates the human circulation. Nat Med 9: 1498-1505

Dickey JS, Baird BJ, Redon CE, Sokolov MV, Sedelnikova OA, Bonner WM (2009) Intercellular communication of cellular stress monitored by gamma-H2AX induction. Carcinogenesis 30: 1686-1695

Fenech M (2007) Cytokinesis-block micronucleus cytome assay. Nat Protoc 2: $1084-1104$

Gow MD, Seymour CB, Ryan LA, Mothersill CE (2010) Induction of bystander response in human glioma cells using high-energy electrons: a role for TGF-beta1. Radiat Res 173: $769-778$

Han W, Wu L, Chen S, Bao L, Zhang L, Jiang E, Zhao Y, Xu A, Hei TK, Yu Z (2007) Constitutive nitric oxide acting as a possible intercellular signaling molecule in the initiation of radiation-induced DNA double strand breaks in non-irradiated bystander cells. Oncogene 26: 2330-2339

Han W, Wu L, Chen S, Yu KN (2009) Exogenous carbon monoxide protects the bystander Chinese hamster ovary cells in mixed coculture system after alpha-particle irradiation. Carcinogenesis 31: 275-280

Harada K, Nonaka T, Hamada N, Sakurai H, Hasegawa M, Funayama T, Kakizaki T, Kobayashi Y, Nakano T (2009) Heavy-ion-induced bystander killing of human lung cancer cells: role of gap junctional intercellular communication. Cancer Sci 100: 684-688

Harada T, Kashino G, Suzuki K, Matsuda N, Kodama S, Watanabe M (2008) Different involvement of radical species in irradiated and bystander cells Int J Radiat Biol 84: 809-814

He M, Zhao M, Shen B, Prise KM, Shao C (2011) Radiation-induced intercellular signaling mediated by cytochrome-c via a p53-dependent pathway in hepatoma cells. Oncogene 30: 1947-1955

Ilnytskyy Y, Koturbash I, Kovalchuk O (2009) Radiation-induced bystander effects in vivo are epigenetically regulated in a tissue-specific manner. Environ Mol Mutagen 50: 105-113

Koturbash I, Boyko A, Rodriguez-Juarez R, McDonald RJ, Tryndyak VP, Kovalchuk I, Pogribny IP, Kovalchuk O (2007) Role of epigenetic effectors in maintenance of the long-term persistent bystander effect in spleen in vivo. Carcinogenesis 28: $1831-1838$ 
Lehnert BE, Goodwin EH (1997) A new mechanism for DNA alterations induced by alpha particles such as those emitted by radon and radon progeny. Environ Health Perspect 105(Suppl 5): 1095-1101

Lemay R, Archambault M, Tremblay L, Bujold R, Lepage M, Paquette B (2011) Irradiation of normal mouse tissue increases the invasiveness of mammary cancer cells. Int J Radiat Biol 87: 472-482

Lewis DA, Mayhugh BM, Qin Y, Trott K, Mendonca MS (2001) Production of delayed death and neoplastic transformation in CGL1 cells by radiation-induced bystander effects. Radiat Res 156: $251-258$

Lyng FM, Seymour CB, Mothersill C (2002) Initiation of apoptosis in cells exposed to medium from the progeny of irradiated cells: a possible mechanism for bystander-induced genomic instability? Radiat Res 157: $365-370$

Mancuso M, Pasquali E, Leonardi S, Tanori M, Rebessi S, Di Majo V, Pazzaglia S, Toni MP, Pimpinella M, Covelli V, Saran A (2008) Oncogenic bystander radiation effects in Patched heterozygous mouse cerebellum. Proc Natl Acad Sci USA 105: 12445 - 12450

Matsumoto H, Hayashi S, Hatashita M, Ohnishi K, Shioura H, Ohtsubo T, Kitai R, Ohnishi T, Kano E (2001) Induction of radioresistance by a nitric oxide-mediated bystander effect. Radiat Res 155: 387-396

Morgan WF, Sowa MB (2007) Non-targeted bystander effects induced by ionizing radiation. Mutat Res 616: $159-164$

Nagasawa H, Little JB (1992) Induction of sister chromatid exchanges by extremely low doses of alpha-particles. Cancer Res 52: 6394-6396

Narayanan PK, Goodwin EH, Lehnert BE (1997) Alpha particles initiate biological production of superoxide anions and hydrogen peroxide in human cells. Cancer Res 57: $3963-3971$

Narayanan PK, LaRue KE, Goodwin EH, Lehnert BE (1999) Alpha particles induce the production of interleukin- 8 by human cells. Radiat Res 152: $57-63$

Nathan C (1992) Nitric oxide as a secretory product of mammalian cells. FASEB J 6: $3051-3064$

Ogawa Y, Nishioka A, Kobayashi T, Kariya S, Hamasato S, Saibara T, Nakayama K, Seguchi H, Yoshida S (2002) Mitochondrial cytochrome c release in radiation-induced apoptosis of human peripheral T cells. Int J Mol Med 10: $263-268$

Ogura A, Oowada S, Kon Y, Hirayama A, Yasui H, Meike S, Kobayashi S, Kuwabara M, Inanami O (2009) Redox regulation in radiation-induced cytochrome $\mathrm{c}$ release from mitochondria of human lung carcinoma A549 cells. Cancer Lett 277: $64-71$

Palacios-Callender M, Hollis V, Mitchison M, Frakich N, Unitt D, Moncada S (2007) Cytochrome c oxidase regulates endogenous nitric oxide availability in respiring cells: a possible explanation for hypoxic vasodilation. Proc Natl Acad Sci USA 104: 18508-18513

Peixoto PM, Ryu SY, Pruzansky DP, Kuriakose M, Gilmore A, Kinnally KW (2009) Mitochondrial apoptosis is amplified through gap junctions. Biochem Biophys Res Commun 390: 38-43

Riley PA (1994) Free radicals in biology: oxidative stress and the effects of ionizing radiation. Int $J$ Radiat Biol 65: $27-33$

Sawant SG, Randers-Pehrson G, Geard CR, Brenner DJ, Hall EJ (2001) The bystander effect in radiation oncogenesis: I. Transformation in $\mathrm{C} 3 \mathrm{H}$ $10 \mathrm{~T} 1 / 2$ cells in vitro can be initiated in the unirradiated neighbors of irradiated cells. Radiat Res 155: $397-401$

Schagger H (2002) Respiratory chain supercomplexes of mitochondria and bacteria. Biochim Biophys Acta 1555: 154-159
Schettino G, Folkard M, Prise KM, Vojnovic B, Held KD, Michael BD (2003) Low-dose studies of bystander cell killing with targeted soft $\mathrm{X}$ rays. Radiat Res 160: 505-511

Seymour CB, Mothersill C (1997) Delayed expression of lethal mutations and genomic instability in the progeny of human epithelial cells that survived in a bystander-killing environment. Radiat Oncol Investig 5: $106-110$

Shao C, Aoki M, Furusawa Y (2001) Medium-mediated bystander effects on HSG cells co-cultivated with cells irradiated by X-rays or a $290 \mathrm{MeV} / \mathrm{u}$ carbon beam. J Radiat Res (Tokyo) 42: 305-316

Shao C, Aoki M, Furusawa Y (2003a) Bystander effect on cell growth stimulation in neoplastic HSGc cells induced by heavy-ion irradiation. Radiat Environ Biophys 42: $183-187$

Shao C, Aoki M, Furusawa Y (2004) Bystander effect in lymphoma cells vicinal to irradiated neoplastic epithelial cells: nitric oxide is involved. J Radiat Res (Tokyo) 45: $97-103$

Shao C, Folkard M, Held KD, Prise KM (2008a) Estrogen enhanced cell-cell signalling in breast cancer cells exposed to targeted irradiation. BMC Cancer 8: 184

Shao C, Folkard M, Michael BD, Prise KM (2005) Bystander signaling between glioma cells and fibroblasts targeted with counted particles. Int J Cancer 116: $45-51$

Shao C, Folkard M, Prise KM (2008b) Role of TGF-betal and nitric oxide in the bystander response of irradiated glioma cells. Oncogene 27: 434-440

Shao C, Furusawa Y, Aoki M, Matsumoto H, Ando K (2002) Nitric oxidemediated bystander effect induced by heavy-ions in human salivary gland tumour cells. Int J Radiat Biol 78: $837-844$

Shao C, Furusawa Y, Kobayashi Y, Funayama T, Wada S (2003b) Bystander effect induced by counted high-LET particles in confluent human fibroblasts: a mechanistic study. FASEB J 17: 1422 - 1427

Shao C, Lyng FM, Folkard M, Prise KM (2006) Calcium fluxes modulate the radiation-induced bystander responses in targeted glioma and fibroblast cells. Radiat Res 166: 479-487

Shao C, Prise KM, Folkard M (2008c) Signaling factors for irradiated glioma cells induced bystander responses in fibroblasts. Mutat Res 638: 139-145

Shao C, Stewart V, Folkard M, Michael BD, Prise KM (2003c) Nitric oxidemediated signaling in the bystander response of individually targeted glioma cells. Cancer Res 63: 8437-8442

Stamler JS, Jia L, Eu JP, McMahon TJ, Demchenko IT, Bonaventura J, Gernert K, Piantadosi CA (1997) Blood flow regulation by S-nitrosohemoglobin in the physiological oxygen gradient. Science 276: 2034-2037

Szabo C, Southan GJ, Thiemermann C (1994) Beneficial effects and improved survival in rodent models of septic shock with S-methylisothiourea sulfate, a potent and selective inhibitor of inducible nitric oxide synthase. Proc Natl Acad Sci USA 91: $12472-12476$

Torres J, Sharpe MA, Rosquist A, Cooper CE, Wilson MT (2000) Cytochrome c oxidase rapidly metabolises nitric oxide to nitrite. FEBS Lett 475: $263-266$

Yang G, Wu L, Chen S, Zhu L, Huang P, Tong L, Zhao Y, Zhao G, Wang J, Mei T, Xu A, Wang Y (2009) Mitochondrial dysfunction resulting from loss of cytochrome c impairs radiation-induced bystander effect. $\mathrm{Br} J$ Cancer 100: 1912 - 1916

Yang H, Asaad N, Held KD (2005) Medium-mediated intercellular communication is involved in bystander responses of X-ray-irradiated normal human fibroblasts. Oncogene 24: 2096-2103

This work is published under the standard license to publish agreement. After 12 months the work will become freely available and the license terms will switch to a Creative Commons Attribution-NonCommercial-Share Alike 3.0 Unported License. 